\title{
Credit Default Swaps and Firms' Financing Policies
}

\begin{abstract}
This paper examines the impact of credit default swaps (CDS) on firms' financing and trade credit policies. Our results indicate firms with CDS trading on their debt increase their equity issuances. Further, firms with CDS trading on their debt and high levels of long-term debt issuances decrease their debt financing. Total and idiosyncratic risks are also higher for firms with CDS trading on their debt. These firms pay their suppliers and collect from their customers quicker. Thus, the impacts of the CDS market are not limited to the borrowing firms but also affect economically connected firms.
\end{abstract}

Keywords: Credit default swaps; capital structure; trade credit.

JEL classification: G32, G30, G20

September 30, 2017 


\section{Introduction}

Credit default swaps (CDS) allow creditors to hedge borrowing firms' credit risk and have become a significant component of the U.S. financial markets. ${ }^{1}$ Yet this growth has not come without debate. CDS and other derivatives have been called "financial weapons of mass destruction" and blamed for the 2008 financial crisis. ${ }^{2}$ Stulz (2010), however, concludes that CDS did not cause the credit crisis and that eliminating over-thecounter trading of CDS could reduce social welfare. The debate regarding CDS has prompted recent research to examine the impact of CDS on borrowing firms.

Saretto and Tookes (2013) find CDS trading enables firms to hold more debt for longer time periods. This may be because banks are more likely to hedge safer borrowers’ loans with CDS (Beyhaghi, Massoud, and Saunders, 2017). Subrahmanyam, Tang, and Wang (2016) argue the higher levels of debt resulting from CDS trading prompts some firms to increase their cash holdings. However, even with higher cash holdings, firms with CDS trading on their debt have a higher cost of debt (Ashcraft and Santos, 2009) and greater likelihood of bankruptcy (Subrahmanyam, Tang, and Wang, 2014). Additionally Narayanan and Uzmanoglu (2017) find that the cost of capital increases while investment and firm value decrease for firms with CDS trading on their debt. The possible impacts of CDS trading on the firm's financing decisions has received less attention in the literature. ${ }^{3}$ To this end, this paper examines the impacts of CDS

\footnotetext{
${ }^{1}$ The CDS market grew from less than $\$ 2$ trillion in 2002 to nearly $\$ 60$ trillion by 2007 (Deutsche Bank, 2009). The Deutsche Bank defines CDS as: "An agreement between two parties whereby one party pays the other a fixed coupon over a specified term. The other party makes no payment unless a specified credit event such as a default occurs, at which time a payment is made and the swap terminates."

2002 Berkshire Hathaway annual report (http://www.berkshirehathaway.com/2002ar/2002ar.pdf) and Stout (2009).

${ }^{3}$ See Augustin, Subrahmanyam, Tang, and Wang (2016) for a review of the CDS literature.
} 
trading not only on the borrowing firm's debt financing, but also their equity and trade credit financing decisions.

We expect CDS trading to affect firms' financing policies because capital supply frictions impact firms' capital structure decisions. Specifically, access to capital markets is an important determinant of firms' debt use and firms that can access to public debt markets use more debt (Faulkender and Petersen, 2005). Capital supply uncertainty increases firms' probability of equity issuances while decreasing firms' probability of debt issuances (Massa, Yasuda, and Zhang, 2013) and capital supply shocks lead firms to decrease net debt issue (Lemmon and Roberts, 2010). Hence, debt capital supply side frictions have significant impacts on firms' capital structure decisions. If capital suppliers' hedging with CDS decreases capital supply frictions (Saretto and Tookes, 2013) and increases supply of funds (Instefjord, 2005, and Hirtle, 2009), then CDS trading should impact firms' debt and equity financing policies.

In addition to debt and equity financing, firms often borrow from their suppliers or loan to their customers through extension of trade credit (Meltzer, 1960, and Murfin and Njoroge, 2015). Murfin and Njoroge (2015) state that trade payables were the second largest liabilities on the U.S. firms' aggregate balance sheets in the year 2009. Given the importance of trade credit, we also study impact of CDS trading on firms' trade credit policies. A firm's ability to access credit from capital suppliers is an important factor in trade credit use (Petersen and Rajan, 1997, and Nilsen, 2002). If CDS trading reduces lenders' exposure to borrowers' credit risk, then CDS should allow borrowing firms easier access to credit markets. Accordingly, easier access to capital may decrease the borrowing firms' need for trade credit. 
Using a sample of U.S. listed firms from 2002 to 2016, we find that CDS trading does affect firms' financing policies. Specifically, we find that firms with CDS trading on their debt increase their net equity issuance. The increase in net equity issuance associated with CDS trading has important implications for the firms. Since the cost of equity capital is higher than the cost of debt capital, increasing equity financing will increase the cost of capital and decrease firm's market value. ${ }^{4}$ We also find that CDS trading affects firms' long-term debt policies, though this impact is non-linear. Specifically, for the firms with high (low) long-term debt issuances, CDS trading is negatively (positively) related to long-term debt issuances. The borrowers with the high long-term debt issuances and CDS trading on their debt may substitute equity financing for long-term debt financing. Our results are consistent with Ashcraft and Santos (2009) who find that CDS's impact on firms' cost of debt financing is non-linear. For risky and informally opaque firms, CDS trading increases the cost of debt but for other firms CDS trading does not lower the cost of debt. Our results imply that CDS trading has a direct impact on the firm's long-term capital structure choices.

Another important effect of these changes in capital structure choices is their impact on the firms' risk profiles. Uncertainty in bond investors' capital supply can lead firms to shift their investor bases from bond holders to equity holders and banks (Massa, Yasuda, and Zhang, 2013). Subrahmanyam, Tang, and Wang (2014) find that CDS trading increases the firm's default risk and probability of credit downgrade which in turn may lead to an increase in bond investors' uncertainty. Thus, increased equity issues associated with CDS trading can be a result of shifts in the firm's investor base. Also,

\footnotetext{
${ }^{4}$ Narayanan and Uzmanoglu (2017) find that CDS trading is positively related to the increasing cost of capital and decreasing market value.
} 
using CDS allows banks to approve more risky loans (Instefjord, 2005, and Hirtle, 2009) and the increased risk in the loans approved may lead to increasing borrower riskiness. We find that CDS trading is positively associated with the firm's total risk and firmspecific risk. Hence, CDS trading impacts firms' capital structure choices as well as their risk profiles.

Finally, we find that CDS trading does not affect firms' short-term debt issuance policies but does impact firms' accounts payable and accounts receivable ratios. Specifically, firms with CDS trading on their debt pay their accounts payable faster but also collect their accounts receivable faster. These findings extend the research regarding the impact of CDS on firms' short-term liquidity. Subrahmanyam, Tang, and Wang (2016) find that firms hold more cash after the inception of CDS trading on their debt, and that firms with greater financial expertise hold more cash when their debt is referenced by CDS. Our findings indicate that, in addition to cash holdings of the firms, CDS trading affects accounts receivable and accounts payable accounts. These results imply that the CDS market matters not only to the borrowing firms but also to the borrowing firms' customers and suppliers.

In addition to expanding the research about the CDS market, our study also contributes to the growing literature on the importance of customer and supplier link among firms. Large customers' slower payments are associated with important expenditure cutbacks at the supplier level (Murfin and Njoroge, 2015). Return predictability takes place across economically related assets (Cohen and Frazzini, 2008) and industry profits along supply chain are correlated (Menzly and Ozbas, 2010). Growth shocks to the customer firms are transmitted to supplier firms (Kelly, Lustig, and Van 
Nieuwerburgh, 2013), and bankruptcy filings of customer firms affect their supplier firms (Hertzel, Li, Officer, and Rodgers, 2008). Related to these studies, our findings show that CDS trading affects firms' accounts payable and accounts receivable policies. Since these accounts are important connections between customer and supplier firms, our findings indicate that CDS trading impacts not only the borrowing firms but also economically connected firms.

\subsection{Literature and hypothesis development}

\subsection{Credit default swaps and financing decisions}

Massa, Yasuda, and Zhang (2013) study the impact of capital supply uncertainty on leverage and debt maturity. They find that capital supply uncertainty has a negative relation to the firm's probability of issuing bonds and commercial paper, but has a positive effect on the firm's probability of issuing equity and borrowing from banks. They suggest that the firm responds to an increase in capital supply uncertainty of its investor base by moving away from bonds into equity and bank loans. Also, Lemmon and Roberts (2010) find that firms' debt issuance decreases with credit supply shocks but leverage ratios remain relatively stable.

If CDS trading on borrowing firms' debt decreases capital supply uncertainty, we expect borrowing firms to increase their net debt issuance and decrease their net equity issuances. On the other hand, Subrahmanyam, Tang, and Wang (2014) find that CDS hedging of creditors increases borrowing firms' likelihood of default and credit downgrade. Thus, it is also possible that borrowing firms issue less debt and prefer other financing methods such as equity issues. With these competing arguments, we test following competing hypotheses. 
Hypothesis 1a: Firms with CDS trading on their debt issue more long-term and shortterm debt but less equity.

Hypothesis 1b: Firms with CDS trading on their debt issue less long-term and short-term debt but more equity.

\subsection{Credit default swaps and trade credit financing}

While Ashcraft and Santos (2009) and Saretto and Tookes (2013) focus on impact of CDS on borrowers' debt financing, lending by suppliers to their customers through extension of trade credit is an important source of financing (Meltzer, 1960, and Murfin and Njoroge, 2015). Financial constraints are one of the main reasons for firms' trade credit use. For example, Meltzer (1960) argues when the suppliers faced with extension of credit terms, they either collect their receivables more aggressively or allow the average collection period to lengthen. Meltzer (1960) proposes that firms which accumulate liquidity in periods of easy money use that liquidity to provide trade credit during periods of tight money. Schwartz (1974) suggests that established firms use trade credit to help their younger customers' growth. Petersen and Rajan (1997) find that small firms, with limited access to capital markets, use more trade credit when credit from financial institutions are unavailable, and firms with better access to credit offer more trade credit. Nilsen (2002) finds that small firms and large firms without bond ratings increase trade credit when banks decrease lending. Murfin and Njoroge (2015) find that small and young firms' financial constraints and uncertainty about product quality are important factors of use of trade credit.

If CDS can reduce lenders' exposure to borrowers' credit risk (e.g., Saretto and Tookes, 2013), CDS trading can allow borrowing firms to have an easier access to capital 
markets. In that case, creditors' CDS use can decrease borrowers' trade credit demand. On the other hand, if CDS signal increasing default risk or credit downgrade (Subrahmanyam, Tang, and Wang, 2014), it will be more difficult for firms to obtain credit. The reduced access to capital will increase firms trade credit use. Given these conflicting views, we test the following competing hypotheses:

Hypothesis 2a: Firms with CDS trading on their debt increase their trade credit.

Hypothesis 2b: Firms with CDS trading on their debt decrease their trade credit.

\section{Data and empirical methodology}

\subsection{Data and Empirical Methodology}

Following the methods of Boehmer, Chava and Tookes (2015) and Saretto and Tookes (2013), we collect CDS data for the U.S. firms between 2002 and 2016 from Bloomberg. ${ }^{5}$ In any quarter, in which a CDS price is reported for a firm's debt, we assume CDS are traded on that firm's debt. All other financial data are from Compustat and the Center for Research in Security Prices (CRSP). We delete firms with total assets less than $\$ 10$ million and with negative market value of equity. Also, to avoid any outlier bias, we winsorize our variables at $1 \%$ and $99 \%$. Our final sample has a total of 12,467 firms, of which 1,597 firms have CDS traded on their debt at least one quarter during 2002 to 2016.

We closely follow Lemmon and Roberts (2010) to model the firms' financing policies. To estimate impact of CDS trading on firms' financing policies, we consider the following model:

\footnotetext{
${ }^{5}$ Though Beyhaghi, Massoud, and Saunders (2017) document that CDS market existed since the early 1990s, CDS quote data is first available in 2002 from Bloomberg. Further, CDS use increased significantly after 2003.
} 


$$
Y_{i t}=\alpha_{t}+\eta_{i}+\beta_{1} C D S \_ \text {trading }_{i t}+\sum \beta_{i} X_{i t}+\varepsilon_{i t},
$$

where $Y_{i t}$ is the net equity issuance, net long-term debt issuance or net short-term debt issuance for firm $i$ in quarter $t$. Net equity issuance is defined as sale of common and preferred stock minus purchase of common and preferred stock scaled by start-of-period assets. Net long-term debt issuance is defined as long-term debt issuance minus longterm debt reduction scaled by start-of-period assets. Net short-term debt issuance is defined as change in current debt scaled by start-of-period assets. We proxy CDS_trading with three different CDS proxies: CDS trading binary variable, CDS notional amount, and CDS bid-ask spread. CDS trading binary variable is an indicator variable equal to one if there is a traded CDS on the firm's debt during the quarter. CDS notional amount (in $\$ 100$ billions) is the sum of CDS contracts bought (or equivalently sold) for all warehouse contracts in aggregate, by sector or for single reference entities displayed (as reported by Bloomberg). CDS bid-ask spread is calculated following Hasbrouck and Seppi (2001) as the CDS contract ask price minus CDS contract bid price. ${ }^{6} \alpha_{t}$ and $\eta_{i}$ represents year and firm-fixed effects. $X$ is the vector of control variables, described below, which includes cash flows, market to book ratio, natural logarithm of sale, Altman's Z-score, financial distress, term spread, corporate bond spread, and market return.

We choose three proxies for CDS_trading since a possible concern in binary variable approach is that CDS firms could be different from non-CDS firms based on unobservable factors. To address this concern, we employ firm-fixed effects models,

\footnotetext{
${ }^{6}$ Our bid and ask quotes are limited as they are reported by just contributing dealers. As Saretto and Tookes (2013) note the sampling of a small group of dealers should not be systematically related to the firms financing decisions.
} 
which account for time-invariant differences between firms. We also completely avoid selection biases by focusing only on the CDS firm sample. Specifically, we focus on the notational (dollar) amount of CDS and the liquidity (bid-ask spread) of CDS trading on firms' debt rather than the existence of CDS trading (a binary variable). Thus, the notional amount and bid-ask spread proxies are defined for only CDS firms and document the impact of CDS trading on financing policies of only those firms with CDS trading on their debt. ${ }^{7}$

DeAngelo, DeAngelo, and Stulz (2010) argue the availability of internal funds affects firms' financing decisions: firms with high cash flows have higher internal funds. Thus, we control for cash flows in our financing policy regressions. We define cash flows as income before extraordinary items scaled by book value of assets, as in Lemmon and Roberts (2010). Market-to-book (M/B) ratio is associated with growth prospects, thus we expect M/B to be related to firms' financing decisions. ${ }^{8}$ Market-to-book ratio is defined as market value of equity plus total debt minus deferred tax and investment tax credits scaled by book value of assets. Since larger firms have lower asymmetric information and easier access to capital markets (Saretto and Tookes, 2013), we use the logarithm of total sales as a proxy for firm size.

DeAngelo, DeAngelo, and Stulz (2010) find that financial distress affects firms' security issuance decisions. Thus, we control for financial distress with two proxies: Altman's Z-score and a financial distress binary variable. Altman's Z-score is defined as: $[(3.3)($ pre-tax income $)+($ sales $)+(1.4)($ retained earnings $)+(1.2)($ current assets - current

\footnotetext{
${ }^{7}$ Our second approach is similar to those of Saretto and Tookes (2013) and Narayanan and Uzmanoglu (2017).

${ }^{8}$ If the market considers the firm to have poor growth prospects, the stock price is low and market-to-book ratio is low (Chan and Chen, 1991).
} 
liabilities $) \div$ (book value of assets)]. The financial distress binary variable is equal to one if either i) the firm's earnings before interest, taxes, depreciation, and amortization (EBITDA) is less than its reported interest expense for the previous two years or, ii) EBITDA is less than $80 \%$ of its interest expense in the previous year.

Market conditions are also important factors for firms' financing decisions (Lemmon and Roberts, 2010). Specifically, timing of market conditions can affect firms' security issue decisions (Baker and Wurgler, 2002). Hence, we control for market conditions with three proxies: term spread, corporate bond spread, and market return. We define term spread as yield spread between the 1- and 10-year Treasury bonds, corporate bond spread as yield spread between BAA- and AAA-rated corporate bonds, and equity market return as CRSP value-weighted return.

To examine impact of CDS trading on firms' risk, we estimate the following equation:

$$
Y_{i t}=\alpha_{t}+\eta_{i}+\beta_{1} C D S \_ \text {trading }_{i t}+\sum \beta_{i} X_{i t}+\varepsilon_{i t},
$$

where $Y_{i t}$ is firm $i$ 's risk in quarter $t$. We use three different proxies for the firm's risk: market risk, idiosyncratic risk, and total risk. Market risk is measured as the regression coefficient, $\beta$, in the following CAPM model estimated each quarter: $r_{i, t}-r_{f, t}=\alpha_{i, t}+\beta_{i, t}$ $\times\left(r_{m, t}-r_{f, t}\right)+u_{i, t}$, where $r_{i, t}$ is firm $i$ 's daily stock return at time $t, r_{m, t}$ is CRSP valueweighted market return, and $r_{f, t}$ is the risk-free rate (1-month T-bill rate). Daily stock returns and market returns are obtained from the CRSP database. T-bill rate is obtained from the Federal Reserve (FED). Idiosyncratic risk is defined as the standard deviation of residuals from the quarterly CAPM regression. Total risk is calculated as the standard 
deviation of the daily returns in that quarter for an individual firm. ${ }^{9} \alpha_{t}, \eta_{i}$, and $C D S \_$trading are as previously defined. $X_{i t}$ is a vector of control variables. We consider risk as a function of market-to-book ratio, size, z-score, term spread, market return, cash flows and financial distress. ${ }^{10}$ Specifically, to control for impact of firms' financial strength and growth opportunities on firms' risk, we include cash flows and M/B ratio in our regressions. The impact of information asymmetry on firms' risk is proxied using firm size measured as the logarithm of total sales. ${ }^{11}$ The potential for financial distress is proxied two ways: the firm's Z-score and a distress binary variable. Also, we control impact of market conditions on firms' risk with three proxies: term spread, corporate bond spread, and market return.

To estimate impact of CDS trading on firms' trade credit policies, we follow Murfin and Njoroge (2015) and test following baseline specification:

$$
Y_{i t}=\alpha_{t}+\eta_{i}+\beta_{1} C D S_{-} \text {trading }_{i t}+\beta_{2} \text { Cash }_{-} \text {flows }_{i t}+\beta_{3} \log (\text { Tot.assets })_{i t}+\varepsilon_{i t} \text {, }
$$

where $Y_{i t}$ is accounts receivable and accounts payable ratios for firm $i$ in quarter $t$. Similar to Petersen and Rajan (1997) and Murfin and Njoroge (2015), we define accounts receivable ratio as trade accounts receivable scaled by sales, and accounts payable ratio as accounts payable scaled by cost of goods sold. $\alpha_{t}, \eta_{i}$, and $C D S \_$trading are as previously defined. Meltzer (1960) finds that financial constraints are important determinants of trade credit. Thus, we control for the impact of operating profitability on trade credit use with cash flows (as in Murfin and Njoroge, 2015). Petersen and Rajan

\footnotetext{
${ }^{9}$ These proxies are calculated following Fung, Wen, and Zhang (2012). The Appendix provides calculation details.

10 These variables are defined as in the equation 1.

${ }^{11}$ Saretto and Tookes (2013) argue that larger firms have lower asymmetric information and easier access to capital markets.
} 
(1997) and Nilsen (2002) show small firms use more trade credit so we control for firm size measured as the natural logarithm of total assets.

The Appendix provides detailed definitions of all variables. Table 1 presents the descriptive statistics of our sample. Table 1 shows that during our sample period mean equity, long-term debt, and short-term debt issuances are positive. However, median value for all types of capital issuances are zero, and at $25^{\text {th }}$ percentiles we observe negative values in all types of capital issuances. Thus, the firms' financing policies vary during our sample period. Similarly, we observe high variations in firms' trade credit use in our sample. The mean notional amount for CDS is around $\$ 4.63$ billion, and average difference between CDS bid and ask prices is around \$7. Our sample firms' average market values are higher than their average book values and mean market return, term spread, and corporate bond spreads are all positive. While average total risk and idiosyncratic risk similar, the average market risk is higher than the other risk proxies.

$\{$ Insert Table 1\}

\section{Empirical findings}

\subsection{Univariate comparisons}

Table 2 presents a univariate comparison of means and medians of firms with CDS trading on their debt (CDS firms) and firms without CDS trading on their debt (noCDS firms). Compared to no-CDS firms, CDS firms have lower equity, short-term debt, and long-term debt issuances on average. No-CDS firms' mean trade credit use is higher than that of CDS firms. While no-CDS firms have higher market-to-book ratios, CDS firms are larger and have higher sales. No-CDS firms' idiosyncratic and total risks are greater than those of CDS firms. This is consistent with the findings of Beyhaghi, 
Massoud, and Saunders (2017) who find that banks are more likely to hedge safer borrowers' loans with CDS and to sell riskier borrowers' loans. On the other hand, CDS firms have higher market risk. All stated differences are statistically significant at 5\% or better level.

$\{$ Insert Table 2\}

\subsection{Multivariate analysis}

\section{2.a CDS trading and firm's net equity issuance}

Table 3 presents estimation of the equation (1) and analyzes the impact of CDS trading on firms' net equity issuances. In model 1, we proxy CDS trading with CDS trading binary variable that is defined for all firms in our sample. In models 2 and 3, we proxy CDS trading with CDS notional amount and bid-ask spread. The regressions include firm and year-fixed effects, the standard errors are clustered at firm level, and robust t-statistics are reported in the parentheses.

Table 3 model 1 indicates a positive relation between CDS trading and the firms' net equity issuance. That is, firms that have CDS trading on their debt issue more equity than the firms without CDS on their debt. Model 2 shows that dollar amount of CDS traded on a firm's debt also affects the firm's equity issuance. Among the CDS firms as the notional amount of CDS increases so does firms' net equity issuance. Model 3 shows that as the illiquidity of firms increases (bid-ask spread increases), CDS firms issue more equity. In other words, firms with CDS that are difficult to trade (i.e., CDS with low liquidity) on their debt issue more equity compared to other CDS firms. Our findings in Table 3 indicate that CDS trading has significant impacts on firms' capital structures.

$\{$ Insert Table 3\} 
The increased equity issuance associated with CDS trading has important implications for the firms. Since the cost of equity capital is higher than the cost of debt capital, increasing equity financing leads to an increase in the cost of capital. Our findings support the findings of Narayanan and Uzmanoglu (2017) that CDS trading is positively associated with the increasing cost of capital.

Increased equity issuance may also indicate that CDS firms shift their investor bases from debtholders to equity holders. According to Massa, Yasuda, and Zhang (2013) capital supply uncertainty of bond investors can lead firms to shift their investor bases from bondholders to equity holders and banks. Since CDS trading is associated with increased default risk and probability of credit downgrade (Subrahmanyam, Tang, and Wang, 2014), it is expected that CDS trading signals increased uncertainty for bond investors. Thus, our finding of increased equity issuance associated with CDS trading is consistent with view that CDS trading increases uncertainty for bond investors.

In Table 3, we also find that cash flows are negatively related to net equity issuance. Consistent with market timing hypothesis (Baker and Wurgler, 2002), marketto-book ratio is positively related to net equity issuance. Firms with high sales issue less equity as do firms with higher risk (Z-score). Financial distress binary variable, term spread, corporate bond spread, and market returns are also negatively associated with firms' net equity issuance.

\section{2.b CDS trading and firm's long-term and short-term debt issuances}

Next, we analyze the impact of CDS trading on firms' net long-term and shortterm debt issuances. Again, we estimate equation (1) proxying for CDS trading with CDS trading binary variable, CDS notional amount, and CDS bid-ask spread. As reported 
earlier, the regressions include firm and year-fixed effects, the standard errors are clustered at firm level, and robust t-statistics are reported in the parentheses. In Table 4 model 1 shows that firms with CDS trading on their debt decrease their net long-term debt issuance. Interestingly, model 2 documents a positive relation between CDS notional amount and firms' net long-term debt issuances. As shown in model 3, there is a statistically insignificant relation between CDS bid-ask spread and firms' net long-term debt issuances. These findings imply that while existence and dollar amount of CDS trading on firms' debt matter for long-term debt issuances, ease of CDS trading does not affect the long-term debt polices. To understand why the binary CDS variable and notional amount of CDS trading produce different results for net long-term debt issuance, we employ quantile regressions $(\mathrm{QR})$.

$\{$ Insert Table 4\}

Quantile regression (QR), developed by Koenker and Bassett (1978), extends the regression model to conditional quantiles of the dependent variable, such as the 10th or 90th percentiles. While the ordinary least-squares (OLS) estimates the mean of response variable conditional on explanatory variables, QR estimates the relation between independent variables and dependent variable, conditional on percentiles of dependent variable. QR's flexibility for modeling data with heterogeneous conditional distributions is its main advantage over OLS. Also, QR makes no distributional assumption about the error term in the model. In short, QR examines how the relation between explanatory and response variables changes depending on the quantile of the response variable (Chen, 2005). 
Table 5 reports our simultaneous-quantile regressions over $10^{\text {th }}, 20^{\text {th }}, 80^{\text {th }}$ and $90^{\text {th }}$ percentiles. $^{12}$ The quantile regressions find a positive (negative) and statistically significant relations between CDS trading and long-term debt issuances in low (high) percentiles. Thus, impact of CDS trading on net long-term debt issuance is non-linear. For the firms with low (high) net long-term debt issuances, CDS trading has a positive (negative) effect on net long-term debt issuance.

At first glance, these findings seem to conflict with findings of Saretto and Tookes (2013) that firms increase their leverage and extend debt maturity with CDS trading on their debt. There are two reasons for our differing results. First, Saretto and Tookes (2013) define leverage ratio as total debt divided by firm value. Since CDS introduction decreases firm value (Narayanan and Uzmanoglu, 2017), the leverage ratio can increase even if total debt remains same or decrease to a certain level. Second, an increase or decrease in debt issuance does not always imply an increase or decrease in leverage ratios. For example, Lemmon and Roberts (2010) find that firms' debt issuance decreases with credit supply shocks but leverage ratios remain relatively stable. In addition, we also find that for some firms (lower net long-term debt issuance quantiles) CDS trading is positively associated with net long-term debt issuance.

\section{$\{$ Insert Table 5}

Overall, results in Table 3, 4, and 5 show that CDS trading is positively related to equity issuances but negatively related to long-term debt issuances for a subset of firms. CDS firms with high long-term debt issuances may substitute equity financing for longterm debt financing. On the other hand, CDS firms with low long-term debt issuances increase both their long-term debt and equity financing. Accordingly, impact of CDS on

\footnotetext{
${ }^{12}$ In our QR estimations, we obtain the robust t-statistics using bootstrapped standard errors.
} 
debt capital supply frictions is not uniform across firms. Consistent with our findings, Ashcraft and Santos (2009) find that CDS's impact on firms' cost of debt financing is not linear. For risky and informally opaque firms CDS trading increase cost of debt financing, but not for other firms.

In Table 6 we explore the relation between CDS trading and firms' net short-term debt issuance. Models 1 and 2 find statistically insignificant relations between CDS trading proxies and firms' net short-term debt issuance. However, model 3 documents that as the illiquidity of CDS increases, firms issue less short-term debt. The findings also show that cash flows are generally negatively related to net short-term debt issuance. Models also document a positive relation between corporate bond spread and net shortterm debt issuance. The generally insignificant findings in Table 6 indicate that CDS trading seems to be only important for the long-term financing policies of firms.

$\{$ Insert Table 6\}

Our findings, so far, document that CDS trading affects firms' long-term capital structure choices. One possible impact of changes in capital structure polices can be on firm's risk profile. As a firm issues more debt and/or equity, the firm's risk profile can change. We know CDS allow banks to approve riskier loans (Instefjord, 2005, and Hirtle, 2009). The increased risk in the loans provided may lead CDS to increase the riskiness of the borrowers. Subrahmanyam, Tang, and Wang (2014) find that credit risk of reference firm increases with CDS trading. Accordingly, it is possible that riskiness of firm may increase with CDS trading.

In Table 7, we examine the possible impacts of CDS trading on firms' risk profiles. Models 1 and 2 document positive and statistically significant relations between 
CDS trading and firms' total and idiosyncratic risks. CDS firms have higher total risk and firm-specific risk compared to no-CDS firms; however, the market risk of CDS firms (model 3) is not statistically different than that of no-CDS firms. Models 4 and 5 document that among firms with CDS on their debt, as the notional amount of CDS increases so does the total and idiosyncratic risks of firms. Again, market risk is statistically insignificant in relation to CDS notional amount (model 6). Models 7, 8, and 9 show that the liquidity of CDS trading matters for firms' total, idiosyncratic, and market risks. Specifically, as the illiquidity of CDS increases, firms' total, idiosyncratic, and market risk increase. Our findings in Table 7 document that CDS trading is positively associated with firms' total risk and firm-specific risk supporting Subrahmanyam, Tang, and Wang (2014). Thus, CDS trading impacts not only the long-term debt and equity a CDS firm chooses but also the firm's risk.

\section{$\{$ Insert Table 7$\}$}

\section{2.c CDS trading and firms' trade credit uses}

Table 8 presents estimation of the equation (3) and analyzes impacts of CDS market on firms' accounts payable and accounts receivable. Table 8 also reports the results from slope tests to examine if CDS trading impacts each component of trade credit differently. We follow the method suggested by Paternoster, Brame, Mazerolle, and Piquero (1998) for our slope tests. The test-statistics are calculated using the following

formula: $Z=\left(\operatorname{Coeff}_{i}-\operatorname{Coeff}_{j}\right) /\left(S E_{i}^{2}+S E_{j}^{2}\right)^{1 / 2}$, where Coeff. is the estimated coefficient and $S E$ is the corresponding standard error.

$\{$ Insert Table 8\} 
Table 8 model 1 shows that CDS trading has a negative impact on firms' accounts payable. Firms with CDS on their debt pay their accounts payable faster compared to firms with no CDS on their debt. Model 2 shows that CDS firms also collect their accounts receivable faster. These findings are consistent with Saretto and Tookes (2013) who suggest CDS trading will lead to less trade credit use. Also, since some CDS firms decrease their long-term debt issue, they may collect their receivables faster to help their financing needs. In addition, the fact that CDS firms pay their accounts payable sooner may mean they need to collect their receivables faster. Thus, the CDS market appears to have far reaching implications not only for CDS firms, but also for the CDS firms' customers.

In model 3, we test if the impact of CDS trading on firms' accounts payable is statistically different than that on firms' accounts receivable. The slope test shows that the impact of CDS trading on firms' accounts payable is greater than that on firms' accounts receivable. Model 1 (2) shows a positive (negative) relation between cash flows and accounts payable (receivable), which is consistent with the trade credit patterns that Murfin and Njoroge (2015) examine. Specifically, even large and highly-rated firms with easy access to capital markets borrow though trade credit. ${ }^{13}$ Our finding implies that even the firms with high cash flows extend trade credit use by extending their accounts payable and reducing their account receivables.

Table 8 models 4 and 5 proxy CDS trading with CDS notional amount. Model 4 shows a positive relation between CDS notional amount and firms' accounts payable ratio. Similarly, model 5 documents a positive relation between CDS notional amount and firms' accounts receivable ratio. As the dollar amount of CDS traded on CDS firms'

\footnotetext{
${ }^{13}$ Murfin and Njoroge (2015) examine causes and consequences of this pattern.
} 
debt increases, so does the firms' accounts payable and receivable ratios. The slope test (model 6) shows that the difference in impacts of CDS notional amount on both ratios is not statistically different from zero. Model 7 shows that as the liquidity of CDS on firms' debt deteriorate, firms' takes less time to pay their accounts payable. Model 8 finds a statistically insignificant relation between CDS's liquidity and firms' accounts receivable ratio. The slope test (model 9) find that the difference in impact of CDS liquidity on firms' accounts payable and receivable ratios is statistically significant. These findings indicate that as the liquidity of CDS traded on firms' debt deteriorates, firms tend to pay their accounts payable faster.

In Table 9, we run QR over $10^{\text {th }}, 20^{\text {th }}, 80^{\text {th }}$ and $90^{\text {th }}$ percentiles to further investigate the different results for the CDS trading binary variable and CDS notional amount. Results indicate negative (positive) and statistically significant relations between dollar amount of CDS traded and accounts payable and receivable ratios for firms with low (high) levels of CDS notational amounts. Similar to long-term debt financing, the impact of CDS trading on firms' trade credit use is non-linear.

\section{$\{$ Insert Table 9\}}

\subsection{SLS approach}

A possible concern in our fixed effects approach is the introduction of CDS on borrower's debt may not be exogenous. Creditors' initiation of CDS on borrowers' debt can be affected by the firm's policies or firm's market valuation. For example, if firm is taking on risky projects and/or market valuation of firm is decreasing, lenders can initiate CDS to protect themselves from increasing credit risk. So far our examinations have addressed endogeneity focusing only on CDS firms by employing CDS' notional amount 
and liquidity as proxies for CDS trading. In this section, we conduct a two-stage least square (2SLS) analysis for our full sample of CDS and no-CDS firms to address this possible concern of endogeneity.

To conduct a 2SLS approach, first, we identify an instrumental variable (IV) that is related to creditor's CDS trading but exogenous to firm's financing policies. We utilize Bank foreign exchange derivatives as our IV similar to Saretto and Tookes (2013) and Subrahmanyam, Tang, and Wang (2014). Minton, Stulz, and Williamson (2009) support using bank foreign exchange derivatives as the IV in their findings that a larger percentage of banks that are buyers of CDS protection also use interest-rate, foreign exchange, equity and commodity derivatives for hedging purposes. Thus, banks that are hedging one portion of their portfolios tend to hedge other components as well. Among these hedging derivatives, hedging with foreign exchange derivatives is least likely to be related to the borrowing firm's market valuation, investment and financing policies. Using Thomson Reuters' syndicated loan data, we identify banks that are book runners for firms' syndicated loans. ${ }^{14}$ We then obtain the banks' derivative positions from the Bank Regulatory Database. Bank foreign exchange derivative is defined as the average amount of the banks' foreign exchange derivatives positions, used for hedging (not trading) purposes, relative to their total assets over the past five years. ${ }^{15}$

Table 10 presents the 2 SLS examination of the relation between CDS trading and firms' financing decisions. Model 1 is the first stage of the 2SLS approach showing that our IV satisfies the relevance condition of 2SLS. Models 2, 3, and 4 present the 2SLS

\footnotetext{
${ }^{14}$ For syndicated loans, book runners are the book managers that lead, originate, structure, and run the books on the deal.

${ }^{15}$ Saretto and Tookes (2013) report that mean of their IV is equal to $1.85 \%$ of total assets with standard deviation of $1.40 \%$. Our IV's mean is equal to $2.28 \%$ of total assets with standard deviation of $1.96 \%$. The small difference may be caused by our larger sample size or longer time period.
} 
examination of impact of CDS trading on firms' net equity, net long-term debt, and net short-term debt issues. Model 2 finds that net equity issuance is positively related CDS trading. Models 3 and 4 find that net long-term and short-term debt issues are not affected by CDS trading. Similar to previous results, the 2 SLS examination shows that CDS firms issue more equity than no-CDS firms. Interestingly CDS firms do not have significantly more or less net debt issuances than the no-CDS firms.

$\{$ Insert Table 10\}

Table 11 presents the 2SLS examination of the relation between firms' trade credit use and CDS trading on their debt. Model 1 presents the first stage examination and finds that foreign exchange IV is statistically significant. The models 2 and 3 present the second stage of the 2SLS analysis. Models 2 and 3 find that CDS trading is positively related to firms' accounts receivable and payable ratios. Again, we find that CDS firms collect and pay quicker than no-CDS firms. The slope test (model 4) finds no difference between the FX IV coefficients of models 2 and 3.

$\{$ Insert Table 11\}

\section{Conclusions}

Though the CDS market has grown dramatically in recent years, the role of the CDS market is still debated (Stout, 2009, and Stulz, 2010). Further, the literature is divided on whether the CDS market helps or hurts borrowing firms. Subrahmanyam, Tang, and Wang (2014) find increased bankruptcy risk for firms with the CDS traded on their debt even though some of these firms hold greater cash balances (Subrahmanyam, Tang, and Wang, 2016). Ashcraft and Santos (2009) find CDS trading increases some firms' cost of debt, and Narayanan and Uzmanoglu (2017) find that CDS trading 
decreases firm value and investments, but increases the cost of capital. However, Saretto and Tookes (2013) find CDS trading reduces capital supply frictions and allows firms to hold more debt for longer periods of time. This paper adds to the literature by investigating the impact of the CDS market on firms' financing decisions.

Results indicate that CDS firms increase their net equity issuance. This is consistent with Narayanan and Uzmanoglu's (2017) findings that CDS trading increases cost of capital and decreases market value. We also document a non-linear impact of CDS trading on firms' long-term debt policies. For CDS firms with high (low) long-term issuances, CDS trading is negatively (positively) associated with long-term debt issuance. In addition, we document that CDS trading increases firms' total risk and firm-specific risk. Thus, CDS trading impacts firms' capital structure choices as well as their risk profiles. We also extend the literature by examining the impact of CDS trading on firms' short-term liquidity. We show that, in addition to cash holdings of the firms, CDS trading affects impacts the firms' trade credit. These findings imply that impacts of the CDS market are not limited to the borrowing firms but also affect economically connected firms. 


\section{References}

Ashcraft, A. B., and Santos, J. A. C., 2009. Has the CDS market lowered the cost of corporate debt? Journal of Monetary Economics 56:514-523.

Augustin, P., Subrahmanyam, M. G., Tang, D. Y., and Wang, S. Q., 2016. Credit default swaps: Past, present, and future. Annual Review of Financial Economics 8, 175196.

Baker, M., and Wurgler, J., 2002. Market timing and capital structure. Journal of Finance $57,1-32$.

Beyhaghi, M., Massoud, N., and Saunders, A., 2017. Why and how do banks lay off credit risk? The choice between retention, loan sales and credit default swaps. Journal of Corporate Finance, 42, 335-355.

Boehmer, E., Chava, S., and Tookes, H. E., 2015. Related Securities and Equity Market Quality: The Case of CDS. Journal of Financial and Quantitative Analysis 50, $509-541$.

Chen, C., 2005. An introduction to quantile regression and the QUANTREG procedure. In Proceedings of the Thirtieth Annual SAS Users Group International Conference. Cary, NC: SAS Institute Inc.

Chan, K. C., and Chen, N. F., 1991. Structural and return characteristics of small and large firms. Journal of Finance, 1467-1484.

Cohen, L., and Frazzini, A., 2008. Economic links and predictable returns. The Journal of Finance, 63(4), 1977-2011. 
DeAngelo, H., DeAngelo, L., and Stulz, R. M., 2010. Seasoned equity offerings, market timing, and the corporate lifecycle. Journal of Financial Economics,95(3), 275295.

Faulkender, M., and Petersen, M. A., 2005. Does the source of capital affect capital structure? The Review of Financial Studies, 19(1), 45-79.

Fung, H. G., Wen, M. M., and Zhang, G., 2012. How does the use of credit default swaps affect firm risk and value? Evidence from US life and property/casualty insurance companies. Financial Management, 41(4), 979-1007.

Hasbrouck, J., and Seppi, D. J. 2001. Common factors in prices, order flows, and liquidity. Journal of Financial Economics, 59(3), 383-411.

Hertzel, M. G., Li, Z., Officer, M. S., and Rodgers, K. J., 2008. Inter-firm linkages and the wealth effects of financial distress along the supply chain. Journal of Financial Economics, 87(2), 374-387.

Hirtle, B., 2009. Credit derivatives and bank credit supply. Journal of Financial Intermediation 18:125-150.

Instefjord, N., 2005. Risk and hedging: Do credit derivatives increase bank risk? Journal of Banking and Finance 29: 333-345.

Kelly, B., Lustig, H., and Van Nieuwerburgh, S., 2013. Firm Volatility in Granular Networks (No. w19466). National Bureau of Economic Research.

Koenker, R., and Bassett Jr, G., 1978. Regression quantiles. Econometrica: Journal of the Econometric Society, 33-50. 
Lemmon, M., and Roberts, M. R., 2010. The response of corporate financing and investment to changes in the supply of credit. Journal of Financial and Quantitative Analysis, 45(3), 555-587.

Massa, M., Yasuda, A., and Zhang, L., 2013. Supply uncertainty of the bond investor base and the leverage of the firm. Journal of Financial Economics, 110(1), 185214.

Meltzer, A., 1960. Mercantile Credit, Monetary Policy and the Size of the Firms, Review of Economics and Statistics 42, 429-437.

Menzly, L., and Ozbas, O., 2010. Market Segmentation and Cross-predictability of Returns. The Journal of Finance, 65(4), 1555-1580.

Minton, B. A., Stulz, R., and Williamson, R., 2009. How much do banks use credit derivatives to hedge loans? Journal of Financial Services Research,35(1), 1-31.

Murfin, J., and Njoroge, K., 2015. The implicit costs of trade credit borrowing by large firms. Review of Financial Studies, 28(1), 112-145.

Narayanan, R. P., and Uzmanoglu, C., 2017. Credit Default Swaps and Firm Value. Journal of Financial and Quantitative Analysis, Forthcoming.

Nilsen, J. H., 2002. Trade Credit and the Bank Lending Channel, Journal of Money, Credit and Banking 34:1 226-253.

Paternoster, R., Brame, R., Mazerolle, P., and Piquero, A., 1998. Using the correct statistical test for the equality of regression coefficients. Criminology, 36, 859.

Petersen, M. A., and Rajan, R. G., 1997. Trade credit: theories and evidence. Review of financial studies, 10(3), 661-691. 
Saretto, A., and Tookes, H., 2013. Corporate Leverage, Debt Maturity and Credit Default Swaps: The Role of Credit Supply. Review of Financial Studies 26:1190-1247.

Schwartz, R. A., 1974. An economic model of trade credit, Journal of Financial and Quantitative and Financial Analysis 9, 643-657.

Stout, L. A., 2009. Regulate OTC derivatives by deregulating them. Regulation, 32, 30.

Stulz, R. M. 2010. "Credit Default Swaps and the Credit Crisis." Journal of Economic Perspectives 24, 73-92.Subrahmanyam, M. G., Tang, D. Y., and Wang, S. Q., 2014. Does the tail wag the dog? The effect of credit default swaps on credit risk. Review of Financial Studies 27:2926-2960.

Subrahmanyam, M. G., Tang, D. Y., and Wang, S. Q., 2016. Credit Default Swaps and Corporate Cash Holdings. Journal of Financial Economics, Forthcoming

Wooldridge, J. M., 2012. Introductory Econometrics: A Modern Approach, (Boston: Cengage Learning). 


\section{Table 1: Descriptive statistics}

This table summarizes main descriptive statistics of our sample. Our analysis is based on quarterly data. Our sample consists of all U.S. listed firms from 2002 to 2016. Our sample has total 12,467 firms, and 1,597 firms have CDS traded on their debt at least one quarter during our sample period. We filter firms with total assets less than $\$ 10$ million and with negative market value of equity. All variables are winsorized at $1 \%$ and $99 \%$. Detailed specifications of variable calculations are given in the Appendix.

\begin{tabular}{lcccccc}
\hline Variable & Mean & 25th Pctl & Median & 75 th Pctl & Std Dev & $\mathrm{N}$ \\
\hline Net equity issue & 0.0169 & -0.0002 & 0.0000 & 0.0034 & 0.0925 & 298350 \\
LT debt issue & 0.0094 & -0.0065 & 0.0000 & 0.0059 & 0.0671 & 299563 \\
ST debt issue & 0.0017 & -0.0008 & 0.0000 & 0.0008 & 0.0356 & 174308 \\
Acc. payable ratio & 26.4655 & 0.3122 & 0.5626 & 1.2799 & 92.3272 & 335930 \\
Acc. receivable ratio & 6.3775 & 0.4143 & 0.6536 & 1.0992 & 15.2336 & 334494 \\
Net trade credit & 20.4026 & -0.2942 & 0.0178 & 0.5791 & 82.1247 & 330959 \\
Notional amount (\$ Bill.) & 4.6332 & 0.0000 & 0.0000 & 4.9282 & 10.1613 & 48923 \\
CDS bid-ask & 0.0742 & 0.0000 & 0.0466 & 0.0998 & 0.1152 & 62007 \\
Cash flows & -0.0047 & -0.0054 & 0.0044 & 0.0169 & 0.0541 & 341931 \\
M/B ratio & 1.5458 & 0.7395 & 1.0986 & 1.8093 & 1.3794 & 263466 \\
Log(sales) & 4.1550 & 2.5339 & 4.0985 & 5.7268 & 2.3472 & 341982 \\
Log(tot. assets) & 6.3305 & 4.7350 & 6.2460 & 7.7444 & 2.1555 & 340511 \\
Z-score & -0.2249 & -0.3111 & 0.4981 & 1.1079 & 2.7319 & 257670 \\
Distress & 0.2289 & 0.0000 & 0.0000 & 0.0000 & 0.4201 & 341982 \\
Term spread & 1.8759 & 1.5400 & 2.0100 & 2.6900 & 1.0306 & 341983 \\
Corp. spread & 1.1202 & 0.8900 & 0.9800 & 1.2500 & 0.4729 & 341983 \\
Market return & 0.4232 & -1.5039 & 1.0606 & 2.7941 & 4.1124 & 341921 \\
Idios. risk & 0.0272 & 0.0142 & 0.0215 & 0.0330 & 0.0221 & 258559 \\
Total risk & 0.0303 & 0.0167 & 0.0245 & 0.0366 & 0.0228 & 258559 \\
Market risk & 0.9572 & 0.4882 & 0.9321 & 1.3730 & 0.9329 & 258641 \\
\hline & & & & & &
\end{tabular}


Table 2: Univariate comparison of CDS and no-CDS firms

This table summarizes comparison of means and medians of firms with CDS trading on their debt (CDS) and firms without CDS on their debt (no-CDS). Sample consists of all U.S. listed firms from 2002 to 2016. Statistical significance of mean differences is tested using t-tests, and those of medians are tested with Wilcoxon tests. Symbols *,**, and *** indicate statistical significance at $10 \%, 5 \%$ and $1 \%$ levels, respectively. Detailed specifications of variable calculations are given in the Appendix.

\begin{tabular}{lcccccc}
\hline Variable & No-CDS & CDS & Diff. mean & No-CDS & CDS & Diff. median \\
\hline Net equity issuance & 0.0190 & -0.0018 & $0.0207 * * *$ & 0.0000 & 0.0000 & 0.0000 \\
LT debt issuance & 0.0096 & 0.0078 & $0.0019^{* * *}$ & 0.0000 & 0.0000 & 0.0000 \\
ST debt issuance & 0.0019 & 0.0005 & $0.0013 * * *$ & 0.0000 & 0.0000 & 0.0000 \\
Acc. paybl. ratio & 28.6156 & 6.0012 & $22.6144 * * *$ & 0.5640 & 0.5528 & $0.0111^{* * *}$ \\
Acc. recvbl. ratio & 6.7907 & 2.4446 & $4.3462 * * *$ & 0.6596 & 0.5996 & $0.0600^{* * *}$ \\
Net trade credit & 22.1402 & 3.6801 & $18.4601 * * *$ & 0.0164 & 0.0274 & $-0.0110^{* * *}$ \\
Cash flows & -0.0059 & 0.0064 & $-0.0123 * * *$ & 0.0038 & 0.0092 & $-0.0054 * * *$ \\
M/B ratio & 1.5707 & 1.3076 & $0.2630^{* * *}$ & 1.1075 & 1.0257 & $0.0819 * * *$ \\
Log(sales) & 3.8395 & 7.1082 & $-3.2687 * * *$ & 3.8573 & 7.5412 & $-3.6839 * * *$ \\
Log(tot. assets) & 6.0422 & 9.0369 & $-2.9948 * * *$ & 6.0435 & 9.3490 & $-3.3055^{* * *}$ \\
Z-score & -0.3002 & 0.4601 & $-0.7603 * * *$ & 0.4677 & 0.6575 & $-0.1898^{* * *}$ \\
Distress & 0.2358 & 0.1640 & $0.0718^{* * *}$ & 0.0000 & 0.0000 & 0.0000 \\
Term spread & 1.8871 & 1.7708 & $0.1162 * * *$ & 2.0100 & 1.9300 & $0.0800^{* * *}$ \\
Corp. spread & 1.1182 & 1.1389 & $-0.0207 * * *$ & 0.9800 & 0.9700 & $0.0100 * *$ \\
Idios. risk & 0.0282 & 0.0191 & $0.0092 * * *$ & 0.0224 & 0.0148 & $0.0076 * * *$ \\
Total risk & 0.0311 & 0.0234 & $0.0078 * * *$ & 0.0253 & 0.0185 & $0.0068 * * *$ \\
Market risk & 0.9422 & 1.0800 & $-0.1379 * * *$ & 0.9169 & 1.0197 & $-0.1028 * * *$ \\
\hline
\end{tabular}




\section{Table 3: CDS and net equity issuance - fixed effects regressions}

This table presents the results from estimations of equation (1). In all regressions, the dependent variable is net equity issuance. Net equity issuance is defined as sale of common and preferred stock minus purchase of common and preferred stock, scaled by start-of-period assets. CDS trading is an indicator variable equal to one if there is a traded CDS on the firm's debt during the quarter. Notional values (in $\$ 100$ billion) are the sum of CDS contracts bought (or equivalently sold) for all warehouse contracts in aggregate, by sector or for single reference entities displayed. Bid and ask spread is defined as CDS ask price minus CDS bid price. Definitions of control variables are in the Appendix. Sample consists of all US listed firms from 2002 to 2016. The regressions include firm and year-fixed effects. The standard errors clustered at firm level in all models and robust t-statistics (reported in the parenthesis) are used in our analysis. Symbols *, **, and $* * *$ indicate statistical significance at $10 \%, 5 \%$ and $1 \%$ levels, respectively.

\begin{tabular}{|c|c|c|c|}
\hline Variables & $(1)$ & $(2)$ & (3) \\
\hline CDS proxy & CDS trading binary & CDS notional amount & CDS bid-ask \\
\hline \multirow[t]{2}{*}{ CDS Proxy } & $0.0045^{* * *}$ & $0.024 * *$ & $0.014 * * *$ \\
\hline & $(3.029)$ & $(2.356)$ & $(3.439)$ \\
\hline \multirow[t]{2}{*}{ Cash Flows } & $-0.0463 * * *$ & -0.042 & -0.033 \\
\hline & $(-5.194)$ & $(-1.434)$ & $(-1.322)$ \\
\hline \multirow[t]{2}{*}{$\mathrm{M} / \mathrm{B}$ ratio } & $0.0160 * * *$ & $0.006 * * *$ & $0.007 * * *$ \\
\hline & (22.589) & $(2.880)$ & $(3.515)$ \\
\hline \multirow[t]{2}{*}{ Log(sales) } & $-0.0133 * * *$ & $-0.009 * * *$ & $-0.009 * * *$ \\
\hline & $(-13.972)$ & $(-3.201)$ & $(-3.329)$ \\
\hline \multirow[t]{2}{*}{ Z-score } & $0.0039 * * *$ & $0.005 * *$ & $0.004 * *$ \\
\hline & $(6.955)$ & $(2.030)$ & (1.991) \\
\hline \multirow[t]{2}{*}{ Distress } & $-0.0020 *$ & -0.002 & -0.002 \\
\hline & $(-1.815)$ & $(-0.710)$ & $(-0.929)$ \\
\hline \multirow[t]{2}{*}{ Term spread } & $-0.0014 * * *$ & -0.000 & 0.000 \\
\hline & $(-2.678)$ & $(-0.310)$ & (0.199) \\
\hline \multirow[t]{2}{*}{ Corp. spread } & $-0.0013 * * *$ & $-0.003 * * *$ & $-0.003 * * *$ \\
\hline & $(-2.729)$ & $(-2.856)$ & $(-3.549)$ \\
\hline \multirow[t]{2}{*}{ Market ret. } & $-0.0002 * * *$ & -0.000 & -0.000 \\
\hline & $(-4.020)$ & $(-1.435)$ & $(-0.758)$ \\
\hline \multirow[t]{2}{*}{ Constant } & $0.0613 * * *$ & $0.066 * * *$ & $0.058 * * *$ \\
\hline & $(13.966)$ & $(3.393)$ & $(3.421)$ \\
\hline Observations & 211,158 & 23,411 & 29,498 \\
\hline R-squared & 0.0466 & 0.0783 & 0.0743 \\
\hline Firm FE & YES & YES & YES \\
\hline Year FE & YES & YES & YES \\
\hline Clustered SE & YES & YES & YES \\
\hline
\end{tabular}




\section{Table 4: CDS and net long-term debt issuance - fixed effects regressions}

This table presents the results from estimations of equation (1). In all regressions, the dependent variable is net long-term debt issuance. Net long-term debt issuance is defined as long-term debt minus long-term debt reduction, scaled by start-of-period assets. CDS trading is an indicator variable equal to one if there is a traded CDS on the firm's debt during the quarter. Notional values (in $\$ 100$ billion) are the sum of CDS contracts bought (or equivalently sold) for all warehouse contracts in aggregate, by sector or for single reference entities displayed. Bid and ask spread is defined as CDS ask price minus CDS bid price. Definitions of control variables are in the Appendix. Sample consists of all US listed firms from 2002 to 2016. The regressions include firm and year-fixed effects. The standard errors clustered at firm level in all models and robust tstatistics (reported in the parenthesis) are used in our analysis. Symbols *, **, and *** indicate statistical significance at $10 \%, 5 \%$ and $1 \%$ levels, respectively.

\begin{tabular}{|c|c|c|c|}
\hline Variables & $(1)$ & $(2)$ & (3) \\
\hline CDS proxy & CDS trading binary & CDS notional amount & CDS bid-ask \\
\hline \multirow[t]{2}{*}{ CDS Proxy } & $-0.0027 *$ & $0.028 *$ & -0.004 \\
\hline & $(-1.921)$ & $(1.753)$ & $(-0.674)$ \\
\hline \multirow[t]{2}{*}{ Cash Flows } & $-0.0612 * * *$ & $-0.043 *$ & $-0.037 *$ \\
\hline & $(-10.758)$ & $(-1.841)$ & $(-1.840)$ \\
\hline \multirow[t]{2}{*}{$\mathrm{M} / \mathrm{B}$ ratio } & $-0.0007 * *$ & -0.001 & -0.001 \\
\hline & $(-2.529)$ & $(-1.016)$ & $(-1.128)$ \\
\hline \multirow[t]{2}{*}{ Log(sales) } & $0.0039 * * *$ & $0.004 * *$ & $0.006 * * *$ \\
\hline & $(7.805)$ & $(2.525)$ & $(3.451)$ \\
\hline \multirow[t]{2}{*}{ Z-score } & $0.0016^{* * *}$ & -0.000 & -0.001 \\
\hline & $(6.521)$ & $(-0.315)$ & $(-0.719)$ \\
\hline \multirow[t]{2}{*}{ Distress } & $0.0012 *$ & 0.001 & 0.001 \\
\hline & $(1.751)$ & $(0.616)$ & $(0.583)$ \\
\hline \multirow[t]{2}{*}{ Term spread } & $-0.0017 * * *$ & -0.001 & -0.001 \\
\hline & $(-4.572)$ & $(-0.633)$ & $(-0.898)$ \\
\hline \multirow[t]{2}{*}{ Corp. spread } & $0.0017 * * *$ & 0.001 & $0.002 * *$ \\
\hline & $(4.028)$ & $(1.243)$ & $(2.278)$ \\
\hline \multirow[t]{2}{*}{ Market ret. } & 0.0000 & $0.000 * *$ & $0.000^{*}$ \\
\hline & $(0.165)$ & $(2.235)$ & $(1.723)$ \\
\hline \multirow[t]{2}{*}{ Constant } & $-0.0101 * * *$ & $-0.018 *$ & $-0.028 * * *$ \\
\hline & $(-4.160)$ & $(-1.692)$ & $(-2.671)$ \\
\hline Observations & 216,111 & 24,055 & 30,297 \\
\hline R-squared & 0.0101 & 0.0098 & 0.0092 \\
\hline Firm FE & YES & YES & YES \\
\hline Year FE & YES & YES & YES \\
\hline Clustered SE & YES & YES & YES \\
\hline
\end{tabular}


Table 5: CDS and net long-term debt issuance - simultaneous quantile regression

This table presents the results from estimations of simultaneous quantile-regressions. In all regressions, the dependent variable is net long-term debt issuance. Net long-term debt issuance is defined as long-term debt minus long-term debt reduction, scaled by start-of-period assets. CDS proxy is binary variable equal to one if there is a traded CDS on the firm's debt during the quarter. Definitions of control variables are in the Appendix. Sample consists of all US listed firms from 2002 to 2016. The robust t-statistics (reported in parentheses) are obtained using bootstrapped standard errors. Symbols $*, * *$, and $* * *$ indicate statistical significance at $10 \%, 5 \%$ and $1 \%$ levels, respectively.

\begin{tabular}{lcccc}
\hline & $(1)$ & $(2)$ & $(3)$ & $(4)$ \\
VARIABLES & $10^{\text {th }}$ Quantile & $20^{\text {th }}$ Quantile & $80^{\text {th }}$ Quantile & $90^{\text {th }}$ Quantile \\
\hline CDS proxy & $0.009 * * *$ & $0.002^{* * *}$ & $-0.004^{* * *}$ & $-0.023^{* * *}$ \\
& $(14.851)$ & $(9.722)$ & $(-6.288)$ & $(-15.578)$ \\
Cash Flows & $-0.050^{* * *}$ & $-0.010^{* * *}$ & $-0.060^{* * *}$ & $-0.260^{* * *}$ \\
& $(-8.861)$ & $(-4.770)$ & $(-20.614)$ & $(-15.085)$ \\
M/B Ratio & $0.003 * * *$ & $0.001 * * *$ & $-0.001 * * *$ & -0.000 \\
& $(21.886)$ & $(36.388)$ & $(-26.290)$ & $(-1.108)$ \\
Log(sales) & $-0.002^{* * *}$ & $-0.001 * * *$ & $0.003 * * *$ & $0.008 * * *$ \\
& $(-14.396)$ & $(-21.892)$ & $(56.702)$ & $(35.342)$ \\
Z-score & $0.003 * * *$ & $0.001 * * *$ & $-0.000^{* * *}$ & $-0.003 * * *$ \\
& $(17.696)$ & $(13.425)$ & $(-3.484)$ & $(-7.185)$ \\
Distress & $0.003 * * *$ & $0.002^{* * *}$ & $0.006 * * *$ & $0.017 * * *$ \\
& $(3.726)$ & $(7.006)$ & $(16.583)$ & $(13.715)$ \\
Term spread & $-0.003 * * *$ & $-0.001 * * *$ & $-0.002^{* * *}$ & $-0.011^{* * *}$ \\
& $(-10.827)$ & $(-12.144)$ & $(-17.093)$ & $(-16.492)$ \\
Corp. spread & 0.000 & 0.000 & -0.000 & $-0.003 * * *$ \\
& $(0.355)$ & $(0.638)$ & $(-1.519)$ & $(-2.727)$ \\
Market ret. & 0.000 & 0.000 & $-0.000^{* * *}$ & $-0.000^{* * *}$ \\
& $(0.248)$ & $(0.992)$ & $(-6.492)$ & $(-5.481)$ \\
Constant & $-0.029 * * *$ & $-0.009 * * *$ & $0.007 * * *$ & $0.051 * * *$ \\
& $(-33.691)$ & $(-19.261)$ & $(14.154)$ & $(21.143)$ \\
\hline Pseudo R2 & 0.0103 & 0.0076 & 0.0173 & 0.0173 \\
Observations & 216,111 & 216,111 & 216,111 & 216,111 \\
\hline
\end{tabular}


Table 6: CDS and net short-term debt issuance - fixed effects regressions

This table presents the results from estimations of equation (1). In all regressions, the dependent variable is net short-term debt issuance. Net short-term debt issuance is defined as change in current debt scaled by start-of-period assets. CDS trading is an indicator variable equal to one if there is a traded CDS on the firm's debt during the quarter. Gross notional values (in $\$ 100$ billion) are the sum of CDS contracts bought (or equivalently sold) for all Warehouse contracts in aggregate, by sector or for single reference entities displayed. Bid and ask spread is defined as CDS ask price minus CDS bid price. Definitions of control variables are in the Appendix. Sample consists of all US listed firms from 2002 to 2016. The regressions include firm and yearfixed effects. The standard errors clustered at firm level in all models and robust t-statistics (reported in the parenthesis) are used in our analysis. Symbols *, **, and *** indicate statistical significance at $10 \%, 5 \%$ and $1 \%$ levels, respectively.

\begin{tabular}{|c|c|c|c|}
\hline Variables & $(1)$ & $(2)$ & (3) \\
\hline CDS proxy & CDS trading binary & CDS notional amount & CDS bid-ask \\
\hline \multirow[t]{2}{*}{ CDS Proxy } & -0.0000 & -0.0029 & $-0.0060^{*}$ \\
\hline & $(-0.022)$ & $(-0.429)$ & $(-1.657)$ \\
\hline \multirow[t]{2}{*}{ Cash Flows } & $-0.0226 * * *$ & -0.026 & $-0.031 * *$ \\
\hline & $(-5.721)$ & $(-1.547)$ & $(-2.059)$ \\
\hline \multirow[t]{2}{*}{$\mathrm{M} / \mathrm{B}$ ratio } & -0.0000 & $0.001 *$ & $0.001 *$ \\
\hline & $(-0.117)$ & $(1.876)$ & $(1.680)$ \\
\hline \multirow[t]{2}{*}{ Log(sales) } & $0.0019 * * *$ & 0.001 & 0.001 \\
\hline & $(5.313)$ & $(1.429)$ & $(1.209)$ \\
\hline \multirow[t]{2}{*}{ Z-score } & -0.0001 & $-0.001 * *$ & $-0.001 * *$ \\
\hline & $(-0.487)$ & $(-2.137)$ & $(-2.299)$ \\
\hline \multirow[t]{2}{*}{ Distress } & 0.0004 & 0.001 & 0.001 \\
\hline & $(0.766)$ & $(0.887)$ & $(0.948)$ \\
\hline \multirow[t]{2}{*}{ Term spread } & $-0.0012 * * *$ & -0.001 & -0.000 \\
\hline & $(-4.337)$ & $(-0.960)$ & $(-0.717)$ \\
\hline \multirow[t]{2}{*}{ Corp. spread } & $0.0015^{* * *}$ & $0.002 * * *$ & $0.002 * * *$ \\
\hline & $(4.353)$ & $(3.061)$ & $(3.254)$ \\
\hline \multirow[t]{2}{*}{ Market ret. } & 0.0000 & 0.000 & 0.000 \\
\hline & $(0.981)$ & $(1.131)$ & $(1.061)$ \\
\hline \multirow[t]{2}{*}{ Constant } & $-0.0066 * * *$ & $-0.016 * *$ & $-0.013 * *$ \\
\hline & $(-3.832)$ & $(-2.213)$ & $(-2.212)$ \\
\hline Observations & 123,777 & 14,078 & 17,773 \\
\hline R-squared & 0.0064 & 0.0216 & 0.0195 \\
\hline Firm FE & YES & YES & YES \\
\hline Year FE & YES & YES & YES \\
\hline Clustered SE & YES & YES & YES \\
\hline
\end{tabular}


Table 7: CDS and firms' risk profiles fixed effects regressions

This table presents the results from estimations of the equation (2). In the models, dependent variables are total risk, idiosyncratic risk, and market risk. Total risk is the standard deviation of the daily returns for an individual firm. Market risk is the "beta" coefficient of the firm from CAPM model. The standard deviation of residuals from the CAPM regression represents the idiosyncratic risk. CDS trading is an indicator variable equal to one if there is a traded CDS on the firm's debt during the quarter. Notional values (in $\$ 100$ billion) are the sum of CDS contracts bought (or equivalently sold) for all Warehouse contracts in aggregate, by sector or for single reference entities displayed. Bid and ask spread is defined as CDS ask price minus CDS bid price. Definitions of control variables are in the Appendix. Sample consists of all US listed firms from 2002 to 2016. The regressions include firm and year-fixed effects. The standard errors clustered at firm level in all models and robust $t$-statistics (reported in the parenthesis) are used in our analysis. Symbols *,**, and *** indicate statistical significance at $10 \%, 5 \%$ and $1 \%$ levels, respectively.

\begin{tabular}{|c|c|c|c|c|c|c|c|c|c|}
\hline Variables & $\begin{array}{c}(1) \\
\text { Total risk } \\
\end{array}$ & $\begin{array}{c}\text { (2) } \\
\text { Idios. Risk }\end{array}$ & $\begin{array}{c}\text { (3) } \\
\text { Market risk }\end{array}$ & $\begin{array}{c}\text { (4) } \\
\text { Total risk } \\
\end{array}$ & $\begin{array}{c}\text { (5) } \\
\text { Idios. Risk }\end{array}$ & $\begin{array}{c}\text { (6) } \\
\text { Market risk }\end{array}$ & $\begin{array}{c}(7) \\
\text { Total risk }\end{array}$ & $\begin{array}{c}(8) \\
\text { Idios. Risk }\end{array}$ & $\begin{array}{c}(9) \\
\text { Market risk }\end{array}$ \\
\hline CDS proxy & \multicolumn{3}{|c|}{ CDS trading binary } & \multicolumn{3}{|c|}{ CDS notional amount } & \multicolumn{3}{|c|}{ CDS bid-ask } \\
\hline CDS proxy & $\begin{array}{c}0.002 * * * \\
(4.624)\end{array}$ & $\begin{array}{c}0.002 * * * \\
(4.883)\end{array}$ & $\begin{array}{c}0.002 \\
(0.145)\end{array}$ & $\begin{array}{c}0.021 * * * \\
(5.526)\end{array}$ & $\begin{array}{c}0.032 * * * \\
(7.219)\end{array}$ & $\begin{array}{c}0.191 \\
(1.293)\end{array}$ & $\begin{array}{c}0.021 * * * \\
(9.152)\end{array}$ & $\begin{array}{c}0.027 * * * \\
(10.701)\end{array}$ & $\begin{array}{c}0.387 * * * \\
(5.515)\end{array}$ \\
\hline Cash flows & $\begin{array}{c}-0.027 * * * \\
(-11.329)\end{array}$ & $\begin{array}{c}-0.032 * * * \\
(-13.166)\end{array}$ & $\begin{array}{c}-0.419 * * * \\
(-4.659)\end{array}$ & $\begin{array}{c}-0.021 * * * \\
(-3.515)\end{array}$ & $\begin{array}{c}-0.031 * * * \\
(-4.650)\end{array}$ & $\begin{array}{c}-0.507 * * \\
(-2.188)\end{array}$ & $\begin{array}{c}-0.018 * * * \\
(-3.193)\end{array}$ & $\begin{array}{c}-0.026 * * * \\
(-4.263)\end{array}$ & $\begin{array}{l}-0.378^{*} \\
(-1.925)\end{array}$ \\
\hline $\mathrm{M} / \mathrm{B}$ ratio & $\begin{array}{c}-0.001 * * * \\
(-13.276)\end{array}$ & $\begin{array}{c}-0.001 * * * \\
(-12.984)\end{array}$ & $\begin{array}{c}0.064 * * * \\
(7.929)\end{array}$ & $\begin{array}{c}-0.002 * * * \\
(-5.337)\end{array}$ & $\begin{array}{c}-0.002 * * * \\
(-5.416)\end{array}$ & $\begin{array}{c}0.068 * * * \\
(5.630)\end{array}$ & $\begin{array}{c}-0.001 * * * \\
(-5.012)\end{array}$ & $\begin{array}{c}-0.001 * * * \\
(-5.173)\end{array}$ & $\begin{array}{c}0.071^{* * * *} \\
(6.645)\end{array}$ \\
\hline $\log ($ sales $)$ & $\begin{array}{c}-0.001 * * * \\
(-5.966)\end{array}$ & $\begin{array}{c}-0.001 * * * \\
(-4.673)\end{array}$ & $\begin{array}{c}0.066^{* * * *} \\
(9.459)\end{array}$ & $\begin{array}{c}-0.001 * * * \\
(-2.848)\end{array}$ & $\begin{array}{c}-0.001 * * \\
(-2.295)\end{array}$ & $\begin{array}{c}0.063 * * * \\
(3.481)\end{array}$ & $\begin{array}{c}-0.001 * * \\
(-2.460)\end{array}$ & $\begin{array}{c}-0.001 * * \\
(-2.130)\end{array}$ & $\begin{array}{c}0.065 * * * \\
(3.603)\end{array}$ \\
\hline Z-score & $\begin{array}{c}-0.002 * * * \\
(-17.805)\end{array}$ & $\begin{array}{c}-0.002 * * * \\
(-16.355)\end{array}$ & $\begin{array}{c}0.031 * * * \\
(8.351)\end{array}$ & $\begin{array}{c}-0.003 * * * \\
(-5.595)\end{array}$ & $\begin{array}{c}-0.003 * * * \\
(-5.394)\end{array}$ & $\begin{array}{c}0.020 \\
(1.256)\end{array}$ & $\begin{array}{c}-0.003 * * * \\
(-5.722)\end{array}$ & $\begin{array}{c}-0.003 * * * \\
(-5.699)\end{array}$ & $\begin{array}{c}0.019 \\
(1.529)\end{array}$ \\
\hline Distress & $\begin{array}{c}0.002 * * * \\
(6.324)\end{array}$ & $\begin{array}{c}0.002^{* * *} * \\
(6.199)\end{array}$ & $\begin{array}{c}0.019 * * \\
(2.046)\end{array}$ & $\begin{array}{c}0.003 * * * \\
(4.529)\end{array}$ & $\begin{array}{c}0.003 * * * \\
(4.316)\end{array}$ & $\begin{array}{c}0.025 \\
(1.187)\end{array}$ & $\begin{array}{c}0.003 * * * \\
(5.404)\end{array}$ & $\begin{array}{c}0.003 * * * \\
(4.922)\end{array}$ & $\begin{array}{c}0.003 \\
(0.149)\end{array}$ \\
\hline Term spread & $\begin{array}{c}-0.002 * * * \\
(-16.878)\end{array}$ & $\begin{array}{c}-0.003 * * * \\
(-30.881)\end{array}$ & $\begin{array}{c}0.050 * * * \\
(8.256)\end{array}$ & $\begin{array}{c}-0.002 * * * \\
(-9.177)\end{array}$ & $\begin{array}{c}-0.004 * * * \\
(-16.562)\end{array}$ & $\begin{array}{l}0.019^{*} \\
(1.848)\end{array}$ & $\begin{array}{c}-0.001 * * * \\
(-7.389)\end{array}$ & $\begin{array}{c}-0.003 * * * \\
(-15.151)\end{array}$ & $\begin{array}{c}0.024 * * * \\
(2.607)\end{array}$ \\
\hline Market ret. & $\begin{array}{c}0.000 * * * \\
(8.134)\end{array}$ & $\begin{array}{c}0.000 * * * \\
(7.370)\end{array}$ & $\begin{array}{c}0.002 * * * \\
(4.271)\end{array}$ & $\begin{array}{l}0.000^{*} \\
(1.951)\end{array}$ & $\begin{array}{c}0.000 \\
(1.441)\end{array}$ & $\begin{array}{c}0.000 \\
(0.354)\end{array}$ & $\begin{array}{l}0.000 * * \\
(2.049)\end{array}$ & $\begin{array}{l}0.000^{*} \\
(1.723)\end{array}$ & $\begin{array}{c}0.000 \\
(0.063)\end{array}$ \\
\hline Constant & $\begin{array}{c}0.050 * * * \\
(63.088) \\
\end{array}$ & $\begin{array}{r}0.056 * * * \\
(70.077) \\
\end{array}$ & $\begin{array}{c}0.287 * * * \\
(8.723) \\
\end{array}$ & $\begin{array}{c}0.045 * * * \\
(14.937) \\
\end{array}$ & $\begin{array}{c}0.053 * * * \\
(16.301) \\
\end{array}$ & $\begin{array}{c}0.328 * * * \\
(2.611) \\
\end{array}$ & $\begin{array}{c}0.042 * * * \\
(14.980) \\
\end{array}$ & $\begin{array}{c}0.049 * * * \\
(17.064)\end{array}$ & $\begin{array}{c}0.308 * * * \\
(2.635)\end{array}$ \\
\hline Observations & 171,016 & 171,016 & 171,072 & 22,826 & 22,826 & 22,832 & 28,808 & 28,808 & 28,815 \\
\hline R-squared & 0.1472 & 0.1772 & 0.0192 & 0.2120 & 0.2705 & 0.0283 & 0.2184 & 0.2802 & 0.0321 \\
\hline Firm FE & YES & YES & YES & YES & YES & YES & YES & YES & YES \\
\hline
\end{tabular}




\begin{tabular}{llll|lll|lll} 
Year FE & YES & YES & YES & YES & YES & YES & YES & YES & YES \\
Clustered SE & YES & YES & YES & YES & YES & YES & YES & YES & YES \\
\hline
\end{tabular}




\section{Table 8: CDS and trade credit use fixed effects regressions}

This table presents the results from estimations of the equation (3). The dependent variables are accounts payable and accounts receivable ratios. Accounts payable ratio is calculated as accounts payable divided by cost of goods sold. Accounts receivable ratio is defined as trade accounts receivable divided by sales. CDS trading is an indicator variable equal to one if there is a traded CDS on the firm's debt during the quarter. Notional values (in $\$ 100$ billion) are the sum of CDS contracts bought (or equivalently sold) for all warehouse contracts in aggregate, by sector or for single reference entities displayed. Bid and ask spread is defined as CDS ask price minus CDS bid price. Definitions of control variables are in the Appendix. In our slope tests, we follow the methods suggested by Paternoster, Brame, Mazerolle, and Piquero (1998). We calculate the test-statistics with the following formula: $Z=\left(\operatorname{Coeff} f_{i}-\operatorname{Coeff}_{j}\right) /\left(S E_{i}^{2}+S E_{j}^{2}\right)^{1 / 2}$, where Coeff. is the estimated coefficient and $S E$ is the corresponding standard error. Sample consists of all U.S. listed firms from 2002 to 2016. The regressions include firm and year-fixed effects. The standard errors clustered at firm level in all models and robust $\mathrm{t}$-statistics (reported in the parenthesis) are used in our analysis. Symbols *, **, and *** indicate statistical significance at $10 \%, 5 \%$ and $1 \%$ levels, respectively.

\begin{tabular}{|c|c|c|c|c|c|c|c|c|c|}
\hline Variables & $\begin{array}{c}\text { (1) } \\
\text { Acc. paybl. }\end{array}$ & $\begin{array}{c}\text { (2) } \\
\text { Acc. } \\
\text { recvbl. }\end{array}$ & $\begin{array}{c}(3) \\
\text { Difference } \\
\text { in Coeff. }\end{array}$ & $\begin{array}{c}(4) \\
\text { Acc. } \\
\text { paybl. }\end{array}$ & $\begin{array}{l}(5) \\
\text { Acc. } \\
\text { recvbl. }\end{array}$ & $\begin{array}{c}(6) \\
\text { Difference } \\
\text { in Coeff. }\end{array}$ & $\begin{array}{c}\text { (7) } \\
\text { Acc. paybl. }\end{array}$ & $\begin{array}{c}(8) \\
\text { Acc. } \\
\text { recvbl. }\end{array}$ & $\begin{array}{c}(9) \\
\text { Difference } \\
\text { in Coeff. }\end{array}$ \\
\hline CDS proxy & \multicolumn{3}{|c|}{ CDS trading binary } & \multicolumn{3}{|c|}{ CDS notional amount } & \multicolumn{3}{|c|}{ CDS bid-ask } \\
\hline CDS Proxy & $\begin{array}{c}-5.056 * * * \\
(-5.574)\end{array}$ & $\begin{array}{c}-0.668 * * * \\
(-5.894)\end{array}$ & $\begin{array}{c}-4.388 * * * \\
(-4.800)\end{array}$ & $\begin{array}{l}0.137 * \\
(1.648)\end{array}$ & $\begin{array}{l}0.028 * * \\
(2.455)\end{array}$ & $\begin{array}{c}0.109 \\
(1.292)\end{array}$ & $\begin{array}{l}-3.128 * * \\
(-2.517)\end{array}$ & $\begin{array}{c}-0.022 \\
(-0.065)\end{array}$ & $\begin{array}{l}-3.105 * * \\
(-2.411)\end{array}$ \\
\hline Cash flows & $\begin{array}{c}14.460 * * * \\
(7.009)\end{array}$ & $\begin{array}{c}-2.330 * * * \\
(-7.084)\end{array}$ & & $\begin{array}{c}0.634 \\
(0.419)\end{array}$ & $\begin{array}{c}-1.397 * * \\
(-2.398)\end{array}$ & & $\begin{array}{c}-0.909 \\
(-0.733)\end{array}$ & $\begin{array}{c}-1.977 * * * \\
(-3.136)\end{array}$ & \\
\hline Size & $\begin{array}{c}-2.801 * * * \\
(-4.663)\end{array}$ & $\begin{array}{c}0.224 * * * \\
(3.251)\end{array}$ & & $\begin{array}{c}-0.731 \\
(-1.164)\end{array}$ & $\begin{array}{c}0.091 \\
(0.786)\end{array}$ & & $\begin{array}{l}-1.178 * \\
(-1.830)\end{array}$ & $\begin{array}{l}-0.006 \\
(-0.061)\end{array}$ & \\
\hline Constant & $\begin{array}{c}30.899 * * * \\
(8.916)\end{array}$ & $\begin{array}{c}3.942 * * * \\
(9.624)\end{array}$ & & $\begin{array}{c}10.488 * * \\
(2.089)\end{array}$ & $\begin{array}{c}1.460 \\
(1.523)\end{array}$ & & $\begin{array}{c}14.785 * * * \\
(2.906)\end{array}$ & $\begin{array}{c}2.561 * * * \\
(3.069)\end{array}$ & \\
\hline Observations & 335,913 & 334,477 & & 38,087 & 37,915 & & 48,983 & 48,941 & \\
\hline R-squared & 0.0767 & 0.0251 & & 0.0158 & 0.0142 & & 0.0165 & 0.0122 & \\
\hline Firm FE & YES & YES & & YES & YES & & YES & YES & \\
\hline Year FE & YES & YES & & YES & YES & & YES & YES & \\
\hline Clustered SE & YES & YES & & YES & YES & & YES & YES & \\
\hline
\end{tabular}


Table 9: CDS and trade credit use simultaneous quantile regression

This table presents the results from estimations of simultaneous quantile-regressions. In models 1-4 the dependent variables are accounts payable, and in models 5-8 dependent variables are accounts receivable ratios. Accounts payable ratio is calculated as accounts payable divided by cost of goods sold. Accounts receivable ratio is defined as trade accounts receivable divided by sales. CDS proxy is notional values (in $\$ 100$ billion) that are the sum of CDS contracts bought (or equivalently sold) for all warehouse contracts in aggregate, by sector or for single reference entities displayed. Definitions of control variables are in the Appendix. Sample consists of all US listed firms from 2002 to 2016 . The robust t-statistics (reported in parentheses) are obtained using bootstrapped standard errors. Symbols *, **, and *** indicate statistical significance at 10\%, 5\% and $1 \%$ levels, respectively.

\begin{tabular}{|c|c|c|c|c|c|c|c|c|}
\hline VARIABLES & $\begin{array}{c}(1) \\
10^{\text {th }} \text { Quantile }\end{array}$ & $\begin{array}{c}(2) \\
20^{\text {th }} \text { Quantile }\end{array}$ & $\begin{array}{c}(3) \\
80^{\text {th }} \text { Quantile }\end{array}$ & $\begin{array}{c}\text { (4) } \\
90^{\text {th }} \text { Quantile }\end{array}$ & $\begin{array}{c}(5) \\
10^{\text {th }} \text { Quantile }\end{array}$ & $\begin{array}{c}(6) \\
20^{\text {th }} \text { Quantile }\end{array}$ & $\begin{array}{c}(7) \\
80^{\text {th }} \text { Quantile }\end{array}$ & $\begin{array}{c}(8) \\
90^{\text {th }} \text { Quantile }\end{array}$ \\
\hline CDS proxy & $\begin{array}{c}-0.001 * * * \\
(-3.815)\end{array}$ & $\begin{array}{c}-0.001 * * * \\
(-3.453)\end{array}$ & $\begin{array}{c}0.015 * * * \\
(5.199)\end{array}$ & $\begin{array}{c}0.658 * * * \\
(8.677)\end{array}$ & $\begin{array}{c}-0.002 * * * \\
(-4.101)\end{array}$ & $\begin{array}{c}-0.001 * * * \\
(-2.732)\end{array}$ & $\begin{array}{c}0.030 * * * \\
(3.878)\end{array}$ & $\begin{array}{c}0.290 * * * \\
(47.884)\end{array}$ \\
\hline Cash flows & $\begin{array}{l}-0.071 * * \\
(-2.099)\end{array}$ & $\begin{array}{c}-0.044 \\
(-0.879)\end{array}$ & $\begin{array}{c}-3.368 * * * \\
(-8.459)\end{array}$ & $\begin{array}{c}-7.757 * * * \\
(-9.294)\end{array}$ & $\begin{array}{c}-0.611 * * * \\
(-16.692)\end{array}$ & $\begin{array}{c}-0.721 * * * \\
(-10.281)\end{array}$ & $\begin{array}{l}-3.566 * * * \\
(-17.668)\end{array}$ & $\begin{array}{c}-8.840 * * * \\
(-15.839)\end{array}$ \\
\hline Size & $\begin{array}{l}0.025 * * * \\
(24.949)\end{array}$ & $\begin{array}{l}0.031 * * * \\
(25.318)\end{array}$ & $\begin{array}{l}0.115 * * * \\
(32.274)\end{array}$ & $\begin{array}{c}0.298 * * * \\
(14.058)\end{array}$ & $\begin{array}{l}0.016 * * * \\
(12.079)\end{array}$ & $\begin{array}{c}0.009 * * * \\
(7.101)\end{array}$ & $\begin{array}{l}0.071 * * * \\
(31.704)\end{array}$ & $\begin{array}{c}0.477 * * * \\
(28.766)\end{array}$ \\
\hline Constant & $\begin{array}{c}-0.003 \\
(-0.404)\end{array}$ & $\begin{array}{c}0.048 * * * \\
(4.722)\end{array}$ & $\begin{array}{c}0.154 * * * \\
(7.180)\end{array}$ & $\begin{array}{c}-0.380 * * * \\
(-3.398)\end{array}$ & $\begin{array}{c}0.059 * * * \\
(5.026)\end{array}$ & $\begin{array}{l}0.260 * * * \\
(21.123)\end{array}$ & $\begin{array}{c}0.383 * * * \\
(23.110)\end{array}$ & $\begin{array}{c}-1.248 * * * \\
(-18.667)\end{array}$ \\
\hline $\begin{array}{l}\text { Pseudo R2 } \\
\text { Observations }\end{array}$ & $\begin{array}{c}0.002 \\
38,087\end{array}$ & $\begin{array}{l}0.0018 \\
38,087\end{array}$ & $\begin{array}{l}0.0025 \\
38,087\end{array}$ & $\begin{array}{l}0.0193 \\
38,087\end{array}$ & $\begin{array}{l}0.0018 \\
37,915\end{array}$ & $\begin{array}{l}0.0008 \\
37,915\end{array}$ & $\begin{array}{l}0.0071 \\
37,915\end{array}$ & $\begin{array}{c}0.063 \\
37,915\end{array}$ \\
\hline
\end{tabular}




\section{Table 10: Financing policies 2SLS regressions}

This table presents the results from estimations of two staged least squares (2SLS) for financing policy regressions. First stage is a logit specification, in which CDS trading is considered as dependent variable. CDS trading is an indicator variable equal to one if there is a traded CDS on the firm's debt during the quarter. Bank foreign exchange derivative (IV) is defined as the average amount of foreign exchange derivatives of firms' all lenders (Banks) use for hedging (not trading) purposes relative to their total assets over the past five years. In the second stage, we instrument CDS trading variable with foreign exchange derivative variable. Definitions of control variables are in the Appendix. The regressions include year-fixed effects, standard errors clustered at firm level in all models, and robust t-statistics (reported in the parenthesis) are used in our analysis. Symbols *, **, and *** indicate statistical significance at $10 \%, 5 \%$ and $1 \%$ levels, respectively.

\begin{tabular}{|c|c|c|c|c|}
\hline Variables & $\begin{array}{c}(1) \\
1^{\text {st }} \text { stage } \\
\text { of } \\
2 \text { SLS }\end{array}$ & $\begin{array}{c}\text { (2) } \\
\text { 2SLS } \\
\text { Net equity } \\
\text { issuance }\end{array}$ & $\begin{array}{c}(3) \\
2 S L S \\
\text { LT net debt } \\
\text { issuance }\end{array}$ & $\begin{array}{c}\text { (4) } \\
\text { 2SLS } \\
\text { ST net debt } \\
\text { issuance }\end{array}$ \\
\hline FX IV & $\begin{array}{c}9.404 * * * \\
(3.018)\end{array}$ & $\begin{array}{c}0.0314 * * * \\
(4.375)\end{array}$ & $\begin{array}{l}0.0023 \\
(0.240)\end{array}$ & $\begin{array}{l}-0.0028 \\
(-0.596)\end{array}$ \\
\hline Cash flows & $\begin{array}{c}1.056 \\
(0.639)\end{array}$ & $\begin{array}{c}-0.0805^{* *} \\
(-2.151)\end{array}$ & $\begin{array}{l}-0.0068 \\
(-0.150)\end{array}$ & $\begin{array}{l}0.0263 \\
(0.698)\end{array}$ \\
\hline $\mathrm{M} / \mathrm{B}$ ratio & $\begin{array}{l}-0.0721 \\
(-1.068)\end{array}$ & $\begin{array}{c}-0.0062 * * * \\
(-3.794)\end{array}$ & $\begin{array}{c}0.0044^{* * * *} \\
(3.188)\end{array}$ & $\begin{array}{c}0.0028 * * * \\
(2.947)\end{array}$ \\
\hline Log(sales) & $\begin{array}{c}1.284 * * * \\
(22.69)\end{array}$ & $\begin{array}{c}-0.0117 * * * \\
(-8.070)\end{array}$ & $\begin{array}{c}-0.0088 * * * \\
(-4.568)\end{array}$ & $\begin{array}{l}0.0008 \\
(0.888)\end{array}$ \\
\hline Z-score & $\begin{array}{c}-0.372 * * * \\
(-4.097)\end{array}$ & $\begin{array}{c}-0.0058 * * * \\
(-3.537)\end{array}$ & $\begin{array}{l}-0.0012 \\
(-0.708)\end{array}$ & $\begin{array}{l}-0.0004 \\
(-0.309)\end{array}$ \\
\hline Distress & $\begin{array}{l}-0.0410 \\
(-0.230)\end{array}$ & $\begin{array}{l}0.0034 \\
(1.003)\end{array}$ & $\begin{array}{c}-0.0070 * \\
(-1.658)\end{array}$ & $\begin{array}{c}0.0049 * \\
(1.766)\end{array}$ \\
\hline Term spread & $\begin{array}{l}0.0423 \\
(0.401)\end{array}$ & $\begin{array}{l}0.0029 \\
(1.368)\end{array}$ & $\begin{array}{c}-0.0066^{* *} \\
(-2.050)\end{array}$ & $\begin{array}{c}0.0036^{* *} \\
(2.087)\end{array}$ \\
\hline Corp. spread & $\begin{array}{l}0.0832 \\
(0.691)\end{array}$ & $\begin{array}{c}-0.0091 * * * \\
(-3.936)\end{array}$ & $\begin{array}{l}0.0046 \\
(1.082)\end{array}$ & $\begin{array}{l}0.0037 \\
(1.353)\end{array}$ \\
\hline Market ret. & $\begin{array}{l}-0.0038 \\
(-0.394)\end{array}$ & $\begin{array}{l}0.0003 \\
(1.623)\end{array}$ & $\begin{array}{l}-0.0003 \\
(-0.922)\end{array}$ & $\begin{array}{l}0.0003 \\
(1.231)\end{array}$ \\
\hline Constant & $\begin{array}{c}-12.50 * * * \\
(-19.58) \\
\end{array}$ & $\begin{array}{c}0.0881 * * * \\
(7.764) \\
\end{array}$ & $\begin{array}{c}0.0676^{* * *} * \\
(4.080) \\
\end{array}$ & $\begin{array}{c}-0.0259 * * * \\
(-2.878) \\
\end{array}$ \\
\hline Observations & 8,214 & 7,484 & 7,615 & 3,775 \\
\hline R-squared & 0.3866 & 0.061 & 0.044 & 0.025 \\
\hline
\end{tabular}




\section{Table 11: Trade credit 2SLS regressions}

This table presents the results from estimations of two staged least squares for trade credit policy regressions. First stage is a logit specification, in which CDS trading is considered as dependent variable. CDS trading is an indicator variable equal to one if there is a traded CDS on the firm's debt during the quarter. Bank foreign exchange derivative (IV) is defined as the average amount of foreign exchange derivatives of firms' all lenders (Banks) use for hedging (not trading) purposes relative to their total assets over the past five years. In the second stage, we instrument CDS trading variable with foreign exchange derivative variable. Definitions of control variables are in the Appendix. The year-fixed effects are included in the regressions. Standard errors clustered at firm level in all models and robust t-statistics (reported in the parenthesis) are used in our analysis. In our slope tests, we follow the methods suggested by Paternoster, Brame, Mazerolle, and Piquero (1998). We calculate the test-statistics with the following formula: $Z=$ $\left(\right.$ Coeff $\left._{i}-\operatorname{Coeff}_{j}\right) /\left(S E_{i}^{2}+S E_{j}^{2}\right)^{1 / 2}$, where Coeff. is the estimated coefficient and $S E$ is the corresponding standard error. Symbols *, **, and *** indicate statistical significance at $10 \%, 5 \%$ and $1 \%$ levels, respectively.

\begin{tabular}{lcccc}
\hline & $(1)$ & $(2)$ & $(3)$ & $(4)$ \\
VARIABLES & $1^{\text {st }}$ & 2SLS & 2SLS & $\begin{array}{c}\text { Difference } \\
\text { in Coeff. }\end{array}$ \\
\hline FX IV & Stage of 2SLS & Acc. payable & Acc. receivable & 7.425 \\
& $6.421 * *$ & $10.130^{* *}$ & $2.709 * * *$ & $(1.459)$ \\
Cash flows & $(2.389)$ & $(2.013)$ & $(3.688)$ & \\
& 1.705 & $-14.79 * * *$ & $-7.688^{* * *}$ & \\
Size & $(1.286)$ & $(-2.714)$ & $(-4.605)$ & \\
& $1.090^{* * *}$ & -0.244 & 0.0586 & \\
Constant & $(23.49)$ & $(-0.314)$ & $(0.818)$ & \\
& $-12.94 * * *$ & 3.354 & 0.610 & \\
\hline Observations $_{\text {Pseudo R-square }}^{16}$ & $(-25.28)$ & $(0.574)$ & $(1.198)$ & \\
\hline
\end{tabular}

${ }^{16}$ Since the sum of squared IV residuals (SRR) for IV can be larger than the total sum of squares of y (SST), the R-squared from IV estimation can be negative. Also, reporting R-squared for IV estimation is not very useful. The R-squared for IV estimation has no natural interpretation because when independent variables and error terms are correlate, we cannot decompose the variance of dependent variable. In addition, the R-squared for IV estimation cannot be used in the usual way to compute $\mathrm{F}$ tests of joint restrictions. If methods are intended to provide better estimates of the ceteris paribus effect of independent variables on dependent variable when explanatory variable and error terms are correlated; goodness-of-fit is not a factor (Wooldridge (page 501, 2012)). 


\section{Appendix \\ Definition of the Variables}

Compustat data item numbers are reported in parentheses. All data is measured quarterly unless otherwise indicated.

\begin{tabular}{|c|c|}
\hline Variable & Definition \\
\hline CDS trading & $\begin{array}{l}\text { CDS trading is an indicator variable equal to one if there is a traded } \\
\text { CDS on the firm's debt during the quarter. }\end{array}$ \\
\hline CDS notional amount & $\begin{array}{l}\text { The sum of CDS contracts bought (or equivalently sold) for all } \\
\text { warehouse contracts in aggregate, by sector or for single reference } \\
\text { entities displayed. }\end{array}$ \\
\hline CDS bid-ask spread & $\begin{array}{l}\text { End of quarter CDS ask price minus end of quarter CDS bid price. } \\
\text { CDS bid price is the price at which a buyer is prepared to buy } \\
\text { according to the proposed outstanding contract. CDS ask price is the } \\
\text { price at which a seller is ready to sell by the proposed contract. }\end{array}$ \\
\hline Net equity issue & $\begin{array}{l}\text { Sale of common and preferred stock (84) minus purchase of } \\
\text { common and preferred stock (93) scaled by start-of-period assets } \\
(44) \text {. }\end{array}$ \\
\hline Net LT debt issue & $\begin{array}{l}\text { Long-term debt issuance (86) minus long-term debt reduction (92) } \\
\text { scaled by start-of-period assets (44). }\end{array}$ \\
\hline Net ST debt issue & Change in current debt (75) scaled by start-of-period assets (44). \\
\hline Acc. payable ratio & Accounts payable (46) divided by cost of goods sold (30). \\
\hline Acc. receivable ratio & $\begin{array}{l}\text { Accounts receivable (item RECTRQ or RECTQ (37) if RECTRQ is } \\
\text { missing) divided by sales (2). }\end{array}$ \\
\hline Cash flow & $\begin{array}{l}\text { Income before extraordinary items (76), scaled by book value of } \\
\text { assets (44). }\end{array}$ \\
\hline Corporate spread & Yield spread between BAA and AAA rated corporate bonds. \\
\hline Financially distressed & $\begin{array}{l}\text { Financially distressed is an indicator variable equal to one if either i) } \\
\text { the firm's earnings before interest, taxes, depreciation, and } \\
\text { amortization (EBITDA) is less than } 80 \% \text { of its interest expense in } \\
\text { the previous year or, ii) EBITDA is less than its reported interest } \\
\text { expense for the previous two years. }\end{array}$ \\
\hline Market-to-book & $\begin{array}{l}\text { Market value of equity }(61 * 14) \text { plus total debt }(51+45) \text { minus } \\
\text { deferred taxes and investment tax credits }(52) \text {, scaled by book value } \\
\text { of assets }(44) \text {. }\end{array}$ \\
\hline Market return & CRSP annual value-weighted return. \\
\hline Term spread & Yield spread between the 1- and 10-year Treasury bonds. \\
\hline Z-score & $\begin{array}{l}{[(3.3)(\text { pre-tax income })+(\text { sales })+(1.4)(\text { retained }} \\
\text { earnings })+(1.2)(\text { current assets }- \text { current liabilities }) \div(\text { book value of } \\
\text { assets })] .\end{array}$ \\
\hline \multirow[b]{2}{*}{ Market risk $(\beta)$} & $\begin{array}{l}\text { The regression coefficient, } \beta \text {, in the following quarterly CAPM } \\
\text { model }\end{array}$ \\
\hline & $\begin{array}{l}\qquad r_{i, t}-r_{f, t}=\alpha_{i, t}+\beta_{i, t} \times\left(r_{m, t}-r_{f, t}\right)+u_{i, t} \text {, } \\
\text { where } r_{i, t} \text { is firm } i \text { 's daily return at time } t, r_{m, t} \text { is CRSP value- } \\
\text { weighted market return, and } r_{f, t} \text { is the risk-free rate (1-month T-bill } \\
\text { rate). }\end{array}$ \\
\hline
\end{tabular}




\begin{tabular}{l|l}
\hline Idiosyncratic risk & $\begin{array}{l}\text { The standard deviation of residuals from the quarterly CAPM } \\
\text { regression for } \beta .\end{array}$ \\
\hline Total risk & $\begin{array}{l}\text { The standard deviation of the daily returns measured quarterly for } \\
\text { an individual firm. }\end{array}$ \\
\hline $\begin{array}{l}\text { Bank Foreign } \\
\text { Exchange Derivative }\end{array}$ & $\begin{array}{l}\text { The average amount of the banks' foreign exchange derivatives } \\
\text { positions, used for hedging (not trading) purposes, relative to their } \\
\text { total assets over the past five years. }\end{array}$ \\
\hline
\end{tabular}

